\title{
Significance of Near-bottom Copepod Aggregations as Food Resources for the Juvenile Red Sea Bream in Shijiki Bay
}

\author{
Masaru Tanaka, ${ }^{* 1}$ Hiroshi Ueda, ${ }^{* 2}$ Masanori Azeta, ${ }^{* 3}$ \\ and Hiroyuki Sudo**
}

(Accepted January 12, 1987)

\begin{abstract}
The significance of copepod swarming near the bottom as food resources for juvenile red sea breams was investigated around the nursery ground of Shijiki Bay. Juveniles of 12.7 to $43.7 \mathrm{~mm}$ FL were found to predate upon a large number of pelagic copepods composed exclusively of Acartia omorii and A. steueri. The maximum number of copepods detected in a stomach increased markedly with juvenile length, reaching about 100 at $13 \mathrm{~mm} \mathrm{FL}, 200$ at $15 \mathrm{~mm}$ FL and exceeding 300 at $20 \mathrm{~mm}$ FL. However, few copepods were found in the stomachs of juveniles larger than $35 \mathrm{~mm}$ FL. The large quantities of ingested copepods observed were inferred to be caused by effective predation on highly aggregated copepods near the bottom.

The estimation for the daily ration of the red sea bream demonstrated that early juveniles can obtain enough energy for maintenance and growth soley through feeding on copepods. Within the bay, densities of copepods swarming near the bottom showed a landward increase. The density gradient induces the early juveniles to migrate into the innermost part of the bay, i.e. the nursery ground.

Together, these quantitative estimates and with qualitative evidence confirm that copepods swarming near the bottom are of great importance for the survival and growth of the early juveniles of the red sea bream, particularly as emergent food resources under deficient conditions of benthic prey organisms.
\end{abstract}

The previous article ${ }^{1)}$ demonstrated how two pelagic copepod species, Acartia omorii and $A$. steueri, are commonly aggregated near the bottom around the nursery ground of the red sea bream, Pagrus major (Temminck et Schlegel), in Shijiki Bay. The juveniles have been reported to voraciously predate the aggregated copepods when they encounter them ${ }^{1-3)}$ and were accordingly regarded as an efficient sampler for the near-bottom copepods in the previous article. ${ }^{1)}$ In the present paper, however, we regard the juveniles as predators of copepods and consider the significance of such aggregations for inshore migration, growth and survival of early juveniles of the red sea bream.

Adaptive advantages of aggregation for copepods have been discussed from various viewpoints; reproduction, feeding, protection against predation, maintenance of position, etc. ${ }^{4-1)}$ How- ever, the fact that aggregated copepods are voraciously predated by fishes has been rarely described, ${ }^{8,8)}$ and the role of such aggregations in the feeding of fishes has never been analyzed and discussed in detail.

For the early juveniles of demersal red sea bream, main food organisms are pelagic Copepoda and benthic Gammaridea. ${ }^{1)}$ The latter is a more important food than the former in a quantitative sense. ${ }^{2)}$ However, since Copepoda is more commonly and densely distributed, it would play an important role for the juveniles when Gammaridea becomes deficient. The main purpose of this study is to describe the predation of aggregated copepods by juvenile red sea breams, and to discuss their role on the survival of the juveniles.

*1 Department of Fisheries, Faculty of Agriculture, Kyoto University, Kyoto 606, Japan (田中 克：京都大 学弯学部水産学科).

*2 Department of Marine Sciences, University of Ryukyus, Nishihira, Okinawa 903-01, Japan (上田拓史：琉 球大学理学部海洋学科).

*3 Research Division of Fishery Agency, Kasumigaseki, Tokyo 100, Japan (畔田正格：水産泞研究部研究集).

*4 Seikai Regional Fisheries Research Laboratory, Nagasaki 850, Japan (首藤宏: 西海区水䃏研究所). 


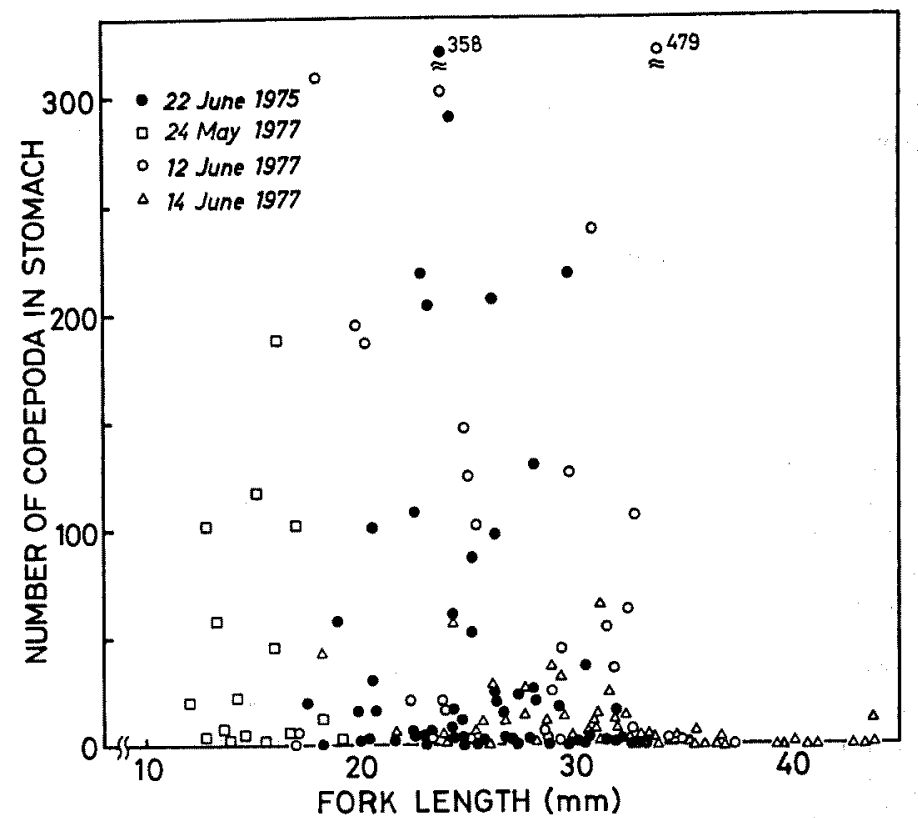

Fig. 1. Number of copepods found in a stomach of juvenile red sea bream. Juveniles were caught with Gochi-trawl and beam-trawl in May and June, 1975 and 1977.

\section{Materials and Methods}

Collections of red sea bream were made in Shijiki Bay, located in the southwestern tip of Hirado Island. Juveniles used for stomach content analysis were caught with Gochi-trawl at $11 \mathrm{G}$-stations, and with beam-trawl at $15 \mathrm{MT}$ stations during late May to late June, 1977. These sampling stations and dates were described in the previous paper. ${ }^{1)}$ Specimens were fixed in about $10 \%$ sea-water formalin immediately after collection. After measuring fork length and wet body weight, their stomachs were removed and the contents were dissected to identify the species and developmental stage of ingested organisms.

A length-weight relationship was determined on another group of juveniles caught with Gochitrawl in mid June, 1983 and 1986. Dry weight of juveniles was measured to $0.01 \mathrm{mg}$ with an electromicrobalance after they had been left in an $60^{\circ} \mathrm{C}$ oven for 72 hours. Dry weights of pelagic copepods were calculated according to Uye. ${ }^{10)}$ The daily ration of juveniles was estimated from the sum of the energy required for metabolism and daily growth. ${ }^{12-14}$ For calculation of the ration, the following data were used: oxygen consumption of the juveniles presented by Anraku and Azeta, ${ }^{13)}$ daily growth of the juveniles by Azeta et al., ${ }^{10)}$ caloric values of fish tissues and oxy-caloric coefficient by Winberg ${ }^{12)}$ and Laurence. ${ }^{17)}$

\section{Results}

\section{Composition of Copepods in Stomachs}

The stomach contents of 220 juveniles, ranging from 12.7 to $43.7 \mathrm{~mm}$ in fork length (FL), were mainly composed of Copepoda, Gammaridea and Mysidacea. Percentage numerical composition in 61 juveniles caught at MT-stations was $81.4 \%$ Copepoda, 14.5\% Gammaridea, 3.6\% Mysidacea, $0.3 \%$ Polychaeta, and $0.08 \%$ Ostracoda and Cumacea. Over $97 \%$ of the copepods were pelagic species. The number of copepods ingested varied greatly, even within the same size class of fish (Fig. 1). The maximum number increased markedly with an increase in juvenile length, reaching about 100 at $13 \mathrm{~mm} \mathrm{FL,} 200$ at $15 \mathrm{~mm}$ FL and over 300 at $20 \mathrm{~mm}$ FL. The maximum number was 479 copepods, found in a juvenile measuring $33.9 \mathrm{~mm}$ FL caught at MT-11 on June 14, 1977. However, usually few copepods were found in the stomachs of juveniles larger than $35 \mathrm{~mm}$ FL.

Species composition of copepods found in the stomachs of the juveniles collected at $11 \mathrm{G}$-stations is shown in Table 1. In the stomachs of 84 juveniles, a total of 1,768 copepods were counted. Benthic Harpacticoida occupied only about $4.3 \%$. Seven pelagic copepod species were identified: Acartia omorii, A. steueri, Paracalanus parvus, Pseudodiaptomus marinus, Corycaeus sp., Stiphos 
Table 1. Species composition of copepods found in stomachs of juvenile red sea breams caught at each G-station on June 14, 1977. Each value indicates the total number of copepods from all juveniles examined

\begin{tabular}{|c|c|c|c|c|c|c|c|c|c|c|}
\hline \multirow{2}{*}{ Food items } & \multicolumn{10}{|c|}{ Stations } \\
\hline & G-1 & G-2 & $\mathrm{G}-3$ & G-4 & G-5 & G-6 & G-7 & G-8 & G-9 & Total \\
\hline Acartia steueri adult & 39 & 7 & & & 46 & 11 & & 3 & 4 & 110 \\
\hline Acartia omoril adult & 22 & 5 & & 2 & 76 & 52 & & 455 & 100 & 712 \\
\hline Acartia immature & 61 & 2 & & 1 & 105 & 41 & & 516 & 99 & 825 \\
\hline Paracalanus parvus & 2 & & & & & & & 4 & 3 & 9 \\
\hline $\begin{array}{l}\text { Pseudodiaptomus } \\
\text { marinus }\end{array}$ & 16 & 1 & & & 5 & 1 & & 4 & 2 & 29 \\
\hline Corycaeus sp. & & & & & 1 & & & & 1 & 2 \\
\hline Stiphos sp. & & & & & & 1 & & 1 & & 2 \\
\hline $\begin{array}{l}\text { Oithona sp. } \\
\text { Unidentified }\end{array}$ & & & & & & & & 1 & & 1 \\
\hline $\begin{array}{l}\text { Unidentified } \\
\text { Copepoda }\end{array}$ & 1 & 1 & & & & & & & & \\
\hline $\begin{array}{l}\text { Copepoda } \\
\text { Benthic }\end{array}$ & & & & & & & & & & 2 \\
\hline Harpacticoida & 22 & 14 & 3 & 4 & 6 & 1 & & 15 & 11 & 76 \\
\hline Total & 163 & 30 & 3 & 7 & 239 & 107 & 0 & 999 & 220 & 1768 \\
\hline $\begin{array}{l}\text { Number of P. major } \\
\text { examined } \\
\text { Copepoda per }\end{array}$ & 19 & 8 & 4 & 4 & 17 & 6 & 1 & 11 & 14 & 84 \\
\hline juvenile & 8.6 & 3.8 & 0.8 & 1.8 & 14.1 & 17.8 & 0 & 90.8 & 15.7 & 21.0 \\
\hline
\end{tabular}

Table 2. Species composition of copepods found in stomachs of juvenile red sea breams caught at each MT-station on June 12, 1977. Each value indicates the total number of copepods from all juveniles examined

\begin{tabular}{|c|c|c|c|c|c|c|}
\hline \multirow{2}{*}{ Species } & \multicolumn{6}{|c|}{ Stations } \\
\hline & MT-1 & MT-2 & MT-3 & MT-6 & MT-7 & MT-8 \\
\hline Acartia omorii adult $q$ & 1 & & 2 & 3 & & 7 \\
\hline$\hat{0}$ & 2 & & & & : & 1 \\
\hline Acartia steueri adult $q$ & 4 & & 4 & & 241 & \\
\hline 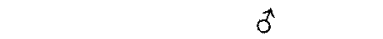 & & & & & 99 & \\
\hline Acartia immature & 7 & & 192 & & 32 & 14 \\
\hline Pseudodiaptomus marinus & 9 & 4 & & & 1 & \\
\hline Stiphos sp. & & & & & & \\
\hline Unknown Cyclopoida sp. & & & & & & \\
\hline Benthic Harpacticoida & 4 & 3 & 3 & 2 & 11 & 2 \\
\hline Total & 27 & 7 & 201 & 5 & 384 & 24 \\
\hline Number of $P$. major examined & 5 & 8 & 5 & 5 & 10 & 5 \\
\hline Copepoda per juvenile & 5.4 & 0.9 & 40.2 & 1.0 & 38.4 & 4.8 \\
\hline
\end{tabular}

Table 2. (Continued)

\begin{tabular}{|c|c|c|c|c|c|c|}
\hline \multirow{2}{*}{ Species } & \multicolumn{6}{|c|}{ Stations } \\
\hline & MT-9 & MT-10 & MT-11 & MT-12 & MT-13 & Total \\
\hline Acartia omorii adult ㅇ & 22 & 29 & 40 & 31 & 22 & 288 \\
\hline$d$ & 8 & 28 & 54 & 23 & 15 & \\
\hline Acartia steueri adult $q$ & 13 & & 227 & 3 & 1 & 709 \\
\hline o & & & 115 & 2 & & \\
\hline $\begin{array}{l}\text { Acartia immature } \\
\text { Pseudodiaptomus marinus }\end{array}$ & 35 & 90 & 768 & 661 & 86 & $\begin{array}{r}1885 \\
14\end{array}$ \\
\hline Stiphos sp. & & & 1 & & 2 & 3 \\
\hline Unknown Cyclopoida sp. & & & & 2 & & 2 \\
\hline Benthic Harpacticoida & 4 & 9 & 22 & & 6 & 66 \\
\hline Total & 82 & 156 & 1227 & 722 & 132 & 2967 \\
\hline Number of $P$. major examined & 7 & 5 & 5 & 5 & 2 & 62 \\
\hline Copepoda per juvenile & 11.7 & 31.2 & 245.4 & 144.4 & 66.0 & 47.9 \\
\hline
\end{tabular}


Table 3. Estimated daily ration of juvenile red sea bream. Daily growth is calculated from an equation of length-weight relationship ( $\log W=3.269 \log L-2.891$ ) and $5.0 \mathrm{cal} / \mathrm{mg}$ dry body weight of fish tissues. $\mathrm{O}_{2}$ consumption is estimated from an equation of $\mathrm{O}_{2}$-weight relationship $\left(Q=0.009 W^{0.714}\right)$. An oxy-caloric coefficient of 4.77 is used. Corrected DR (daily ration) is obtained from dividing daily ration, sum of calories for growth and metabolism, by an assimilation coefficient of 0.8

\begin{tabular}{|c|c|c|c|c|c|c|c|}
\hline \multirow{2}{*}{$\begin{array}{l}\text { Length } \\
\text { (FL mm) }\end{array}$} & \multirow{2}{*}{$\begin{array}{l}\text { Weight } \\
\text { (dry mg) }\end{array}$} & \multicolumn{2}{|c|}{ Daily growth } & \multirow{2}{*}{$\begin{array}{c}\mathrm{O}_{2} \text { cons.* } \\
(\mathrm{m} l / \mathrm{h})\end{array}$} & \multirow{2}{*}{$\begin{array}{c}\text { Metabolism } \\
\text { (cal) }\end{array}$} & \multirow{2}{*}{$\begin{array}{c}\text { Daily ration } \\
\text { (cal) }\end{array}$} & \multirow{2}{*}{$\begin{array}{c}\text { Corrected } \\
\text { DR } \\
\text { (cal) }\end{array}$} \\
\hline & & (mg) & (cal) & & & & \\
\hline 10 & 2.39 & 0.41 & 2.05 & 0.018 & 2.06 & 4.11 & 5.18 \\
\hline 15 & 8.99 & 1.44 & 7.20 & 0.046 & 5.27 & 12.47 & 15.59 \\
\hline 20 & 23.00 & 2.75 & 13.76 & 0.088 & 10.07 & 23.83 & 29.79 \\
\hline 25 & 47.74 & 4.51 & 22.56 & 0.147 & 16.83 & 39.39 & 49.24 \\
\hline 30 & 86.70 & 6.60 & 33.00 & 0.223 & 25.53 & 58.50 & 73.10 \\
\hline 35 & 143.50 & 9.50 & 47.53 & 0.319 & 36.52 & 84.05 & 105.06 \\
\hline 40 & 222.10 & 12.40 & 62.00 & 0.434 & 49.68 & 111.68 & 139.61 \\
\hline 45 & 326.50 & 16.40 & 82.00 & 0.571 & 65.37 & 147.37 & 184.20 \\
\hline
\end{tabular}

* Oxygen consumed by a juvenile $(\mathrm{ml}$ per hour).

sp., and Oithona sp. The two species of Acartia constituted $97.5 \%$ of total pelagic copepods and the latter five species were almost negligible in number. Adult and immature Acartia were present in almost equal proportions. The number of copepods per juvenile differed from 0 to 90.8 ( $\bar{X}=21.0$ ), depending on sampling stations. The maximum number of 90.8 was found at $\mathrm{G}-8$, which was located near a well vegetated Sargassum zone. Within the two Acartia species, $A$. omorii was over 6 times more abundant than A. steueri. This appeared to be caused by differences in distribution pattern; $A$. omorii was rather widely distributed, which $A$. steueri was restricted to a few stations near the shore like G-1 and 5.

Table 2 shows the specific composition of copepods found in the stomachs of juveniles collected at MT-stations. In 62 juvenile stomachs, 2,967 copepods, including only $2.2 \%$ of benthic Harpacticoida, were found. The average number of 47.9 per juvenile was more than twice that recorded from G-stations. Five species of pelagic copepods were found: Acartia omorii, A. steueri, Pseudodiaptomus marinus, Stiphos sp. and Cyclopoida sp. As seen at G-stations, the major portion of the copepods were occupied by $A$. omorii and $A$. steueri, and the other species were almost negligible in number. However, at MT-1 and 2, which were located near the shore of the innermost part of the bay, $P$. marinus was dominant.

The relative proportions of the two species varied with stations; $A$. steueri overwhelmingly predominated over $A$. omorii at MT-7 and 11 , but the opposite trend was seen at MT-6, 8, 10, 12 and

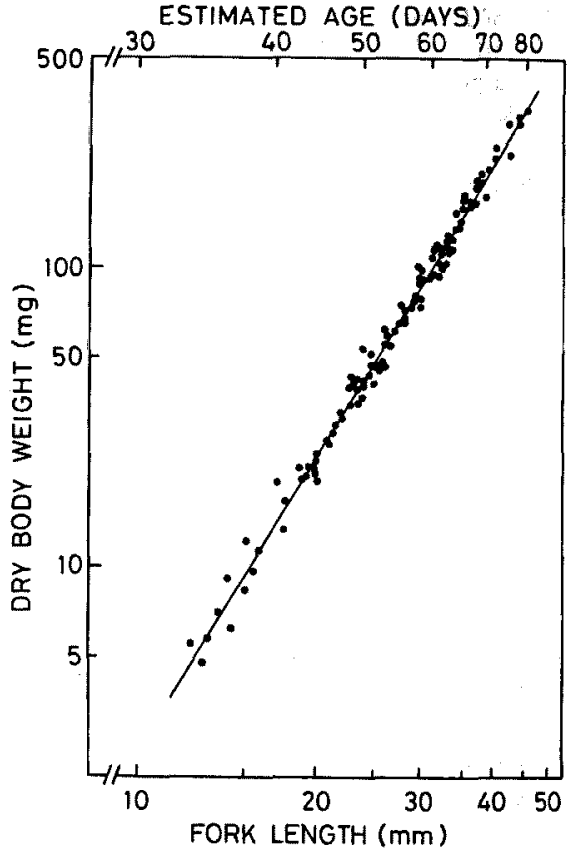

Fig. 2. Length-weight relationship obtained for the juvenile red sea bream caught in June, 1983 and 1986, representing an equation $\log W=$ $3.269 \log L-2.891$ ( $W$ : dry body weight in $\mathrm{mg}$, $L$ : fork length in $\mathrm{mm}$ ). Estimated age (days after hatching) was determined from Azeta et $a l{ }^{16)}$ with an average daily growth of $0.70 \mathrm{~mm}$ and daily growth increment examination of otolith (unpublished).

13, although the number of copepods per each station was not so large. These variations in the relative proportion were also reflected in the contents of stomachs examined at a given station. 
At MT-11, for example, two juveniles exclusively predated upon $A$. omorii and the others exclusively upen $A$. steueri. Sex ratios differed between the two species, being nearly equal in $A$. omorii, whereas in $A$. steueri, females markedly outnumbered males.

\section{Estimation of Daily Ration}

The relationship between fork length and dry body weight of the red sea bream juveniles is shown in Fig. 2. Body weight increased exponentially with an increase in length from $8.99 \mathrm{mg}$ at $15 \mathrm{~mm}$ FL to $222.1 \mathrm{mg}$ at $40 \mathrm{~mm}$ FL. The relationship was expressed by an equation, $\log W=3.269 \times$ $\log L-2.891$, where $W$ and $L$ are dry body weight in $\mathrm{mg}$ and fork length in $\mathrm{mm}$, respectively.

Figure 2 also presents age (days after hatching) equivalent to size, estimated from an average daily growth rate of $0.70 \mathrm{~mm}$ in length for the juveniles ${ }^{15)}$ and $0.34 \mathrm{~mm}$ for the larvae determined by otolith daily growth increments (unpublished). A $15 \mathrm{~mm}$ FL juvenile grows from $8.99 \mathrm{mg}$ to $10.43 \mathrm{mg}$ in a day, resulting in a daily growth of $1.44 \mathrm{mg}$. This may be converted to $7.20 \mathrm{cal}$, assuming $1 \mathrm{mg}$ dry weight of fish tissues $=5.003$ cal. ${ }^{(6)}$

From the relationship between $\mathrm{O}_{2}$ consumption and body weight: $Q=0.009 W^{0.714}$, presented by Anraku and Azeta, ${ }^{14)}$ a $15 \mathrm{~mm}$ juvenile red sea bream requires $0.046 \mathrm{ml} \mathrm{O} \mathrm{O}_{2}$ per hour. The juvenile consumes $1.104 \mathrm{ml} \mathrm{O}_{2}$ during 24 hours, this being equivalent to $5.27 \mathrm{cal}$, assuming an oxy-caloric coefficient of 4.77.11) Thus, from the sum of $7.20 \mathrm{cal}$ for growth and $5.27 \mathrm{cal}$ for metabolism the energy that the juvenile gains from food during 24 hours is calculated as $12.47 \mathrm{cal}$. If the assimilation coefficient is assumed to be $0.8,{ }^{11,12}$ ) the daily ration may be estimated as being 15.59 cal. Similarily the daily ration of a $40 \mathrm{~mm}$ juvenile is calculated as being $139.61 \mathrm{cal}$. Table 3 shows the estimated daily ration in calories for each $5 \mathrm{~mm}$ size class.

\section{Discussion}

Together, the present study and with the previous one ${ }^{1 / 2}$ have clearly demonstrated that red sea bream juveniles predate upon large quantities of copepods swarming near the bottom. One may question whether juveniles can satisfy their energy requirements with only copepods. To answer this question we have to undertake a quantitative analysis. The maximum number in

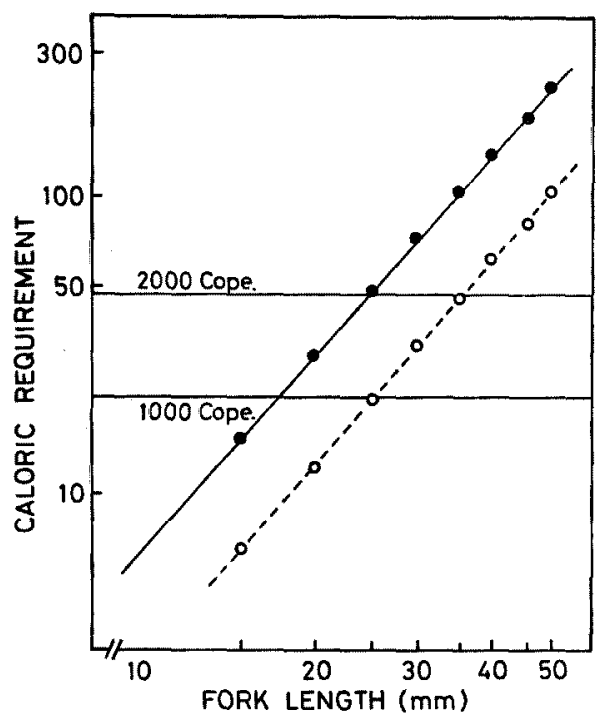

Fig. 3. Daily caloric requirement for red sea bream juveniles. Solid circles show daily ration in calories, and open circles caloric requirement for metabolism only. 1,000 and 2,000 Cope. lines indicate the daily calories obtained by juveniles predating that number.

the stomach of a $15 \mathrm{~mm}$ FL juvenile was about 200 copepods (Fig. 1) and the daily turnover rate of stomach contents may be reasonably assumed to be five times, judging the excretion time ${ }^{17)}$ and hours available for feeding in a day. Therefore, a $15 \mathrm{~mm}$ juvenile could ingest some 1,000 copepods in a day. One thousand individuals of Acartia with $0.8 \mathrm{~mm}$ in body length are equivalent to 5.8 $\mathrm{mg}$ dry weight, using the length-weight relationship of copepods: $\log W=3.061 \log L-8.120$ ( $W: \mu \mathrm{g}, L: \mathrm{mm}$ ) presented by Uye. ${ }^{10)}$ Furthermore, on the basis of their caloric contents ${ }^{18)} 5.8$ $\mathrm{mg}$ of pelagic copepods can be converted into 29.0 cal. Assuming 0.8 digestibility, the juvenile red sea bream could obtain 23.2 cal from 1,000 copepods of $0.8 \mathrm{~mm}$ in length. This value exceeds the daily ration of $15.59 \mathrm{cal}$ (Table 3 ) and we can, therefore, conclude that a juvenile can obtain enough energy only from swarming copepods, at least during its early days.

The importance of copepods decreases in larger juveniles in a quantitative sense. For example, a $30 \mathrm{~mm}$ FL juvenile obtains $58.0 \mathrm{cal}$ from copepods under a maximum ingestion of 400 copepods and a turnover rate of 5 . The value of 46.4 cal corrected by digestibility is less than the daily ration of $73.1 \mathrm{cal}$ (Table 3 and Fig. 3). However, it is higher than the energy required for 


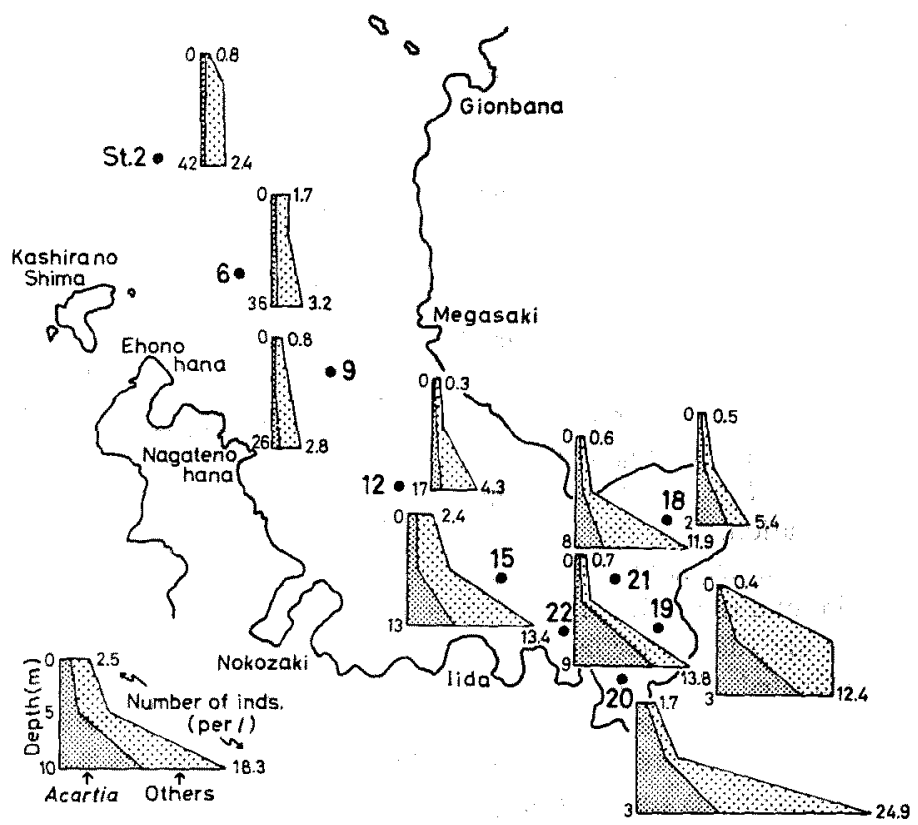

Fig. 4. Horizontal changes in the vertical profile of copepods in Shijiki Bay. Sampling was carried out by horizontal tows of plankton nets at 3 layers on June 22, 1977 (profiles are adapted from Table 1 of previous paper ${ }^{13}$. Numerals on the left of the profiles show towing depths and those on the right, copepod densities per liter.

metabolism 25.5 cal. Figure 3 demonstrates that juveniles smaller than $35 \mathrm{~mm}$ can obtain enough energy for body maintenance from 2,000 copepods, and those smaller than $25 \mathrm{~mm}$, from 1,000 copepods. All estimates in the present calculation are made assuming maximum ingestion. Although a major proportion of juvenile do not always predate upon the copepods near the maximum ingestion level, these estimates appear to verify the quantitative importance of copepods.

Qualitative evidence for the importance of aggregated copepods for red sea bream juveniles has been given ${ }^{18)}$; during years of high population density, early juveniles appeared to depend upon copepods even when over $50 \mathrm{~mm}$ FL. This phenomenon suggests that, under overpopulated conditions in which Gammaridea, their preferred food, are relatively scarce even larger juveniles compensate this energy by ingesting pelagic copepods. These quantitative analyses and qualitative evidence demonstrate the copepod swarms near the bottom around the nursery ground are of very great importance for growth and survival of the juvenile red sea bream; particularly as emergent food resources under deficient conditions of benthic prey animals.

Another significance of aggregated copepods seems to be a role contributing to the inshore migration of the earliest juveniles. The pelagic juveniles, which have already metamorphosed but not yet transferred to demersal life, immigrate from the mouth area to the central area of the bay. There, they encounter Acartia aggregations and synchronization of the diel vertical movement of the predator and prey, dusk-upward and dawndownward, enhances the chance of encounter. Copepod densities near the bottom increase landward as shown in Fig. 4. This gradient contributes to the juveniles newly recruited in the central area moving spontaneously landward, resulting in a high concentration on the bottom of the bay. Gammaridea, the favorite food organism of demersal juveniles, has been reported to occur most abundantly in the innermost area of the bay ${ }^{18)}$ and thus, juvenile red sea breams can smoothly transfer their food habit from pelagic organisms to demersal ones in synchronization with their habitat shift into the nursery ground.

Average population densities of the red sea bream in Shijiki Bay can vary annually as nearly twenty times of the ratio between the lowest and the highest year-class densities. This is mainly attributable to the abundance of recruiting pelagic larvae. ${ }^{20)}$ However, annual population densities 
are also affected to some extent by the annual variations in abundance of swarming copepods. The variation in development of aggregations seems to occur on daily, seasonal and annual time scales; it is more evident on fine days, and develops from spring to early summer, terminating in mid-summer. These variations may influence the survival and growth of the early juveniles, resulting in annual fluctuations in abundance and production. It is necessary to investigate the influence of the variable aspects of copepod aggregations as regulating mechanism for juvenile red sea bream populations in greater detail.

The adaptive significance of copepod swarming has been discussed from various viewpoints. ${ }^{4-7}$ In their observations on copepod swarms on coral reefs, Hamner and Carleton ${ }^{4}$ suggested swarming to be an adaptation evolved by resident plankton species to survive within the reef ecosystem. They also noted that protection from predators is probably the most common adaptive explanation. In the present study, however, swarming was confirmed to be undoubtedly beneficial for effective predation by juvenile red sea bream and this situation is not restricted solely to this species. In Shijiki Bay, evidence for predation on swarming copepods has been provided by stomach content analyses of some juvenile fishes; crimson sea bream* in winter, gobioid fishes $^{21}$ in spring, and Japanese grunt ${ }^{22)}$ in summer. Furthermore, the predation on Acartia by sand eel ${ }^{8)}$ suggests this to be a rather widespread phenomenon in coastal waters.

In the nursery ground of Shijiki Bay, the maximum population density of juvenile red sea bream was estimated by scuba divers using a line transect method, ${ }^{23)}$ as being 0.34 fishes per $\mathrm{m}^{2}$. If we assume a daily consumption of 1000 copepods per fish, 340 copepods per $\mathrm{m}^{2}$ are ingested by a juvenile each day. At the same time, the modest estimation of a swarm density of 100 copepods per $l$, is equivalent to 30,000 per $\mathrm{m}^{2}$ at the swarm thickness of $30 \mathrm{~cm} .{ }^{1)}$ Even without new recruitment, numbers of swarming copepods are adequate to supply foraging juveniles for about 90 days. During the first month of the juvenile stage red sea breams are temporal plankton feeders and thereafter change their food habits from plankton to benthic animals. Furthermore, swarms are daily renewed by the upward nighttime dispersion. ${ }^{24)}$ On the basis of this qualitative and quantitative evidence, we can consider that overpredation on swarms by juvenile fishes might never occur, although it may well influence swarming copepod populations.

\section{Acknowledgments}

We would like to thank the personnel of Seikai Regional Fisheries Research Laboratory for offering us various facilities. We wish to acknowledge valuable discussion held with Dr. M. Anraku and reviewing the manuscript by Mr. A. Rossiter. We are indebted to Mr. and Mrs. Kuriyama for their helpful assistance in the field research.

\section{References}

1) M. Tanaka, H. Ueda, and M. Azeta: Nippon Suisan Gakkaishi, 53, 1537-1544 (1987).

2) K. Kiso: Bull. Seikai Reg. Fish. Res. Lab., 54, 291-306 (1980).

3) M. Tanaka: Trans. Am. Fish. Soc., 114, 471-477 (1985).

4) W. M. Hamner and J. H. Carleton: Limnol. Oceanogr., 24, 1-14 (1979).

5) H. Ueda, A. Kuwahara, M. Tanaka, and M. Azeta: Mar. Ecol. Prog. Ser., 11, 165-171 (1983).

6) M. Omori and W. M. Hamner: Mar. Biol., 72, 190-200 (1982).

7) E. B. Byron, P. T. Whitman, and C. R. Goldman: Limnol. Oceanogr., 28, 378-382 (1983).

8) H. Sekiguchi: Nippon Suisan Gakkaishi, 44, 695 (1978).

9) A. L. Alldredge, B. H. Robinson, A. Fleminger, J. J. Torres, J. M. King, and W. M. Hamner: Mar. Biol., 80, 75-81 (1984).

10) S. Uye: J. Oceanogr. Soc. Japan, 38, 149-157 (1982).

11) G. G. Winberg: Fish. Res. Canada, Trans. Ser., 194 (1956).

12) K. H. Mann: J. Anim. Ecol., 34, 253-275 (1965).

13) R. J. Conover: in "Marine Ecology" (ed. by $O$. Kinne), Vol. IV, John Wiley \& Sons, 1978, pp. 221-500.

14) M. Anraku and M. Azeta: Bull. Seikai Reg. Fish. Res. Lab., 43, 117-131 (1973).

15) M. Azeta, R. Ikemoto, and M. Azuma: Bull. Seikai Reg. Fish. Res. Lab., 54, 259-278 (1980).

16) G. C. Laurence: Fish. Bull., U. S., 75, 529-546 (1977).

17) C. Kitajima: Spe. Rep. Nagasaki Pref. Ins. Fish., 5, 1-92 (1978).

18) K. Kiso: Bull. Seikai Reg. Fish. Res. Lab., 57,

* M. Tomiyama, H. Sudo, M. Azeta, and M. Tanaka: Proc. of the Japan. Soc. Sci. Fish., p. 99, No. 409 (April 2, 1986). 
$31-46(1982)$

19) M. Azuma, M. Azeta, and K. Mitsumaru: Bull. Seikai Reg. Fish. Res. Lab., 59, 101-118 (1983).

20) M. Tanaka: in "Sea Farming Technology of Red Sea Bream" (ed. by M. Tanaka and Y. Matsumiya), Koseisha-Koseikaku, Tokyo, 1986, pp. 59-74.

21) Y. Matsumiya, T. Murakami, T. Suzuki, and M.
Oka: Bull. Seikai Reg. Fish. Res. Lab., 54, 321 331 (1980).

22) Y. Matsumiya and K. Takahashi; Bull. Seikai Reg. Fish. Res. Lab., 59, 23-32 (1983).

23) Y. Matsumiya, Y. Endo, and M. Azeta: Buill. Seikai Reg. Fish. Res. Lab., 54, 315-320 (1980).

24) H. Ueda: Mar. Ecol. Prog. Ser., 35, 65-73 (1987). 